\title{
A Framework with Enriched Fluorinated Sites for Stable Li Metal Cycling
}

\author{
Muqin Wang ${ }^{1,2}$, Zhe Peng ${ }^{2,}{ }^{*}$, Huan Lin ${ }^{1,2}$, Zhendong Li $^{2}$, Jian Liu ${ }^{1,2}$, Zhongmin Ren ${ }^{1,2}$,

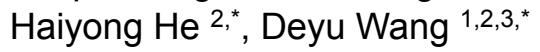 \\ ${ }^{1}$ Key Laboratory of Optoelectronic Chemical Materials and Devices of Ministry of Education, Jianghan University, Wuhan 430056, \\ China. \\ ${ }^{2}$ Ningbo Institute of Materials Technology and Engineering, Chinese Academy of Sciences, Ningbo 315201, Zhejiang Province, \\ China. \\ ${ }^{3}$ Tianmu Lake Institute of Advanced Energy Storage Technologies, Liyang 213300, Jiangsu Province, China.
}

\begin{abstract}
In past decades, lithium-ion batteries (LIBs) were the dominant energy storage systems for powering portable electronic devices because of their reliable cyclability. However, further increase in the energy density of LIBs was met by a bottleneck when low-specificcapacity graphite was used at the anode. Li metal has long been regarded as the ideal anode material for building the next high-energy-density batteries due to its ultrahigh capacity of $3860 \mathrm{mAh} \cdot \mathrm{g}^{-1}$, which is ten times higher than that of graphite. However, using Li metal as an anode in rechargeable batteries is challenging due to its high

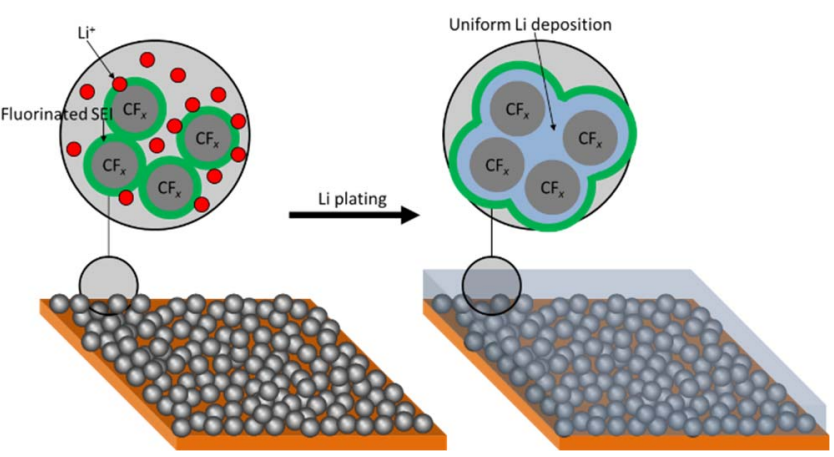
uncontrolled volume expansion and aggressive side reactions with liquid electrolytes. In this study, we demonstrate the effect of a three-dimensional (3D) framework with enriched fluorinated sites for Li metal protection. This framework is obtained via a facile integration of down-sized fluorinated graphite $\left(\mathrm{CF}_{x}\right)$ particles into $\mathrm{Li}^{+}$conducting channels. Thermogravimetry, energy dispersive $\mathrm{X}$-ray spectroscopy, and X-ray photoelectron spectroscopy results show that $\mathrm{Li}^{+}$ conducting channels rich in lithium fluoride $(\mathrm{LiF})$ are formed in situ across the embedded $\mathrm{CF}_{x}$ particles during the initial lithiation process, leading to fast $\mathrm{Li}^{+}$transfer. Scanning electron microscopy results show that residual $\mathrm{CF}_{x}$ particles could act as high-quality nucleation sites for uniform Li deposition inside the framework. These features could not be achieved with a $2 \mathrm{D}$ structure consisting of large $\mathrm{CF}_{x}$ flakes, due to the limited $\mathrm{Li}^{+}$transfer paths and low utilization ratio of $\mathrm{CF}_{x}$ for conversion into LiF-based solid electrolyte interphase (SEI) layers. Consequently, better performance of Li metal anodes in a 3D framework with enriched fluorinated sites is demonstrated. Stable Li plating/stripping over 240 cycles is obtained at a current density of $0.5 \mathrm{~mA} \cdot \mathrm{cm}^{-2}$ for a fixed capacity of $1 \mathrm{mAh} \cdot \mathrm{cm}^{-2}$ by maintaining a voltage hysteresis below $80 \mathrm{mV}$. Improved $\mathrm{Li}-\mathrm{LiFePO}_{4}$ full cell performance with a practical negative/positive capacity ratio of 3 is also demonstrated. These results show the rational combination of well-developed $3 \mathrm{D} \mathrm{Li}{ }^{+}$transfer channels and enriched fluorinated sites as an optimized interfacial design beyond the single use of a 2D fluorinated interface, giving new insight into the protection of $\mathrm{Li}$ metal anodes in high-energy-density batteries.
\end{abstract}

Key Words: Li metal battery; Li metal anode; Fluorinated graphite; Solid electrolyte interphase; Coulombic efficiency

Received: July 6, 2020; Revised: July 29, 2020; Accepted: July 29, 2020; Published online: July 31, 2020.

${ }^{*}$ Corresponding authors. Emails: pengzhe@nimte.ac.cn (Z.P.); hehaiyong@nimte.ac.cn (H.H); wangdeyu@aesit.com.cn (D.W.).

The project was supported by the National Natural Science Foundation of China (51872304), Ningbo 2025 Project, China (2018B10061, 2019B10044) and the National Key R \& D Program of China (2018YFB0905400).

国家自然科学基金(51872304), 宁波市 2025 计划(2018B10061, 2019B10044)和国家重点研发计划(2018YFB0905400)资助项目

(C) Editorial office of Acta Physico-Chimica Sinica 


\title{
一种有助于稳定锂金属循环的富氟化位点框架结构
}

\author{
王木钦 1,2 , 彭哲 $2,{ }^{*}$, 林欢 1,2 , 李振东 ${ }^{2}$, 刘健 ${ }^{1,2}$, 任重民 ${ }^{1,2}$, 何海勇 ${ }^{2,}{ }^{*}$, 王德宇 $1,2,3,{ }^{*}$ \\ 1 江汉大学, 光电化学材料与器件教育部重点实验室, 武汉 430056 \\ 2 中国科学院宁波材料技术与工程研究所, 浙江宁波 315201 \\ 3 天目湖先进储能技术研究院, 江苏溧阳 213300
}

\begin{abstract}
摘要：锂金属是下一代高能量密度二次电池的理想负极材料, 然而它的应用仍然受制于较差的循环稳定性。近期, 二维 氟化界面被广泛用于改善锂金属负极的成核机制、沉积形貌和循环稳定性。本工作通过将体积缩小化的氟化石墨颗粒与 锂离子传导网络结合, 获得了一种富氟化位点的三维框架结构。实验结果证明此类三维氟化结构可显著提升锂金属负极 在不同电流密度和容量下的循环稳定性, 且优于二维氟化界面结构。通过本工作的研究, 证明了相较于单纯的二维氟化 界面, 三维锂离子传导网络和富氟化位点的合理结合可以成为一种改进的界面结构用于锂金属负极保护, 为高能量密度 锂金属电池的负极保护提供了新的设计思路。
\end{abstract}

关键词：锂金属电池；锂金属负极；氟化石墨；固液界面；库伦效率 中图分类号: 0646

\section{Introduction}

The state-of-the-art lithium ion batteries (LIBs) are approaching their theoretic energy limit, and can hardly respond to the requirements from the ever-growing market of portable electronics, electric vehicles and smart energy storage grids ${ }^{1,2}$. During the last decade, Lithium (Li) metal have aroused wide attentions with aim of building next high-energy-density $\mathrm{Li}$ metal batteries (LMBs), due to its ultrahigh specific capacity $\left(3860 \mathrm{mAh} \cdot \mathrm{g}^{-1}\right)$ and the lowest redox potential $(-3.04 \mathrm{~V} v \mathrm{~s}$ Standard Hydrogen Electrode). The high Fermi level of Li metal often leads to large energy gaps against most of the conventional electrolyte solvents, forming a solid electrolyte interphase (SEI) which is helpful to separate $\mathrm{Li}$ from electrolyte in static conditions ${ }^{3}$. However, unlike the graphite anode in LIBs, the native SEI layers pre-formed on the Li surfaces are not able to withstand the uneven deposition and huge volumetric change caused by the delocalized $\mathrm{Li}^{+}$flux on "hostless" Li surface, while the regenerations of SEI layers posterior to the surface cracks are often accompanied by Li and electrolyte consumptions, internal impedance increase and fast fading of coulombic efficiency (CE) of the LMBs ${ }^{4,5}$.

The native SEI layers are generally an inhomogeneous mixture of inorganic species such as $\mathrm{LiF}$ or $\mathrm{Li}_{2} \mathrm{O}$, and organic species such as ROLi and $\mathrm{ROCO}_{2} \mathrm{Li}$, exhibiting poor uniformity for $\mathrm{Li}^{+}$conduction, $\mathrm{Li}$ nucleation and deposition ${ }^{6}$. Interfacial engineering to regulate the SEI layers has been devoted as a main roadmap to stabilize the Li/electrolyte interfaces, including the SEI modification by electrolyte formulations ${ }^{7-13}$ and construction of artificial SEI layers and host structures ${ }^{14-20}$. In particular, fluorine $(\mathrm{F})$ has recently been revealed as a critical element to affect the interfacial stability of Li metal anodes. Enriching the $\mathrm{F}$ content in the SEI layer via electrolyte additives ${ }^{21-24}$, or constructing artificial fluorinated layers have shown prominent effects to boost the cyclability of Li metal anodes ${ }^{25-28}$.

Although the F-containing interfaces exhibit reinforced mechanical stability, high $\mathrm{Li}^{+}$diffusivity and inhibition of dendritic Li growth, the actual efforts are mainly emphasized on the designing of two dimensional (2D) F-containing protective layers to suppress side reactions between $\mathrm{Li}$ metal and electrolytes. Further improvements of using fluorinated structures to afford stable Li metal cycling for higher current densities and capacities are still expected. Herein, we report a three dimensional (3D) framework with enriched fluorinated sites, leading to fast $\mathrm{Li}^{+}$transfer and abundant nucleation sites for uniform $\mathrm{Li}$ deposition inside the framework (Fig. 1b), significantly outperforming the 2D structure consisted of large $\mathrm{CF}_{x}$ flakes (Fig. 1a). The related physic-chemical properties and electrochemical performances of the investigated protective structure for Li metal anodes are explored.

\section{Experimental}

\subsection{Material preparations}

Fluorinated carbon $\left(\mathrm{CF}_{x}\right)$ flakes with $\mathrm{F}$ content above $50 \%$ were purchased from Shanghai CarFluor Chemicals Co., Ltd., and were used as received. The down-sized $\mathrm{CF}_{x}$ particles were obtained using a ball-mill (PM200, Retsch GmbH Inc., Germany) operated at a grinding speed of $400 \mathrm{r} \cdot \mathrm{m}^{-1}$ for $10 \mathrm{~h}$ in ethanol medium, and denoted as $\mathrm{CF}_{x}-400$. The obtained $\mathrm{CF}_{x}-400$ particles were dried under $80{ }^{\circ} \mathrm{C}$ until the ethanol was completely evaporated.

\subsection{Materials characterizations}

The crystalline phases were characterized by X-ray diffraction (XRD) with a Bruker D8 advanced diffractometer using $\mathrm{Cu} K_{\alpha}$ $(\lambda=0.15406 \mathrm{~nm})$ radiation (Bruker axs, D8 Advance). The microstructure analysis was conducted by scanning electron 
(a)

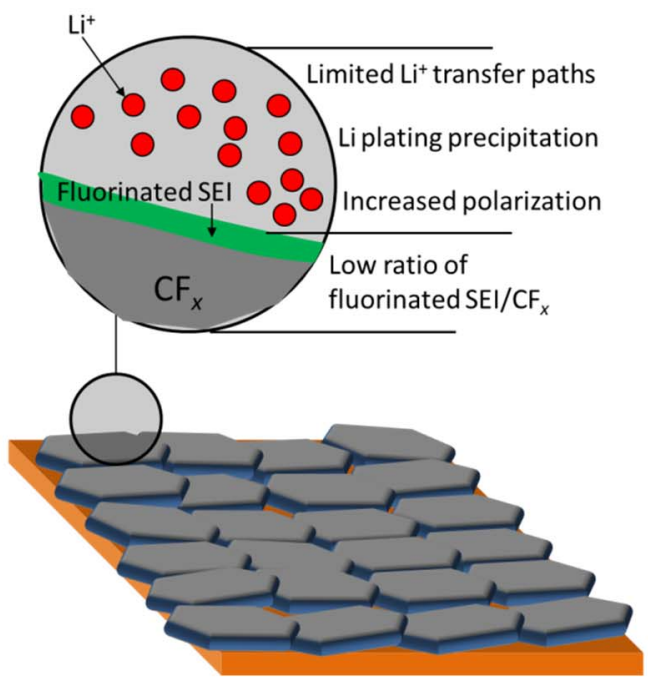

(b)

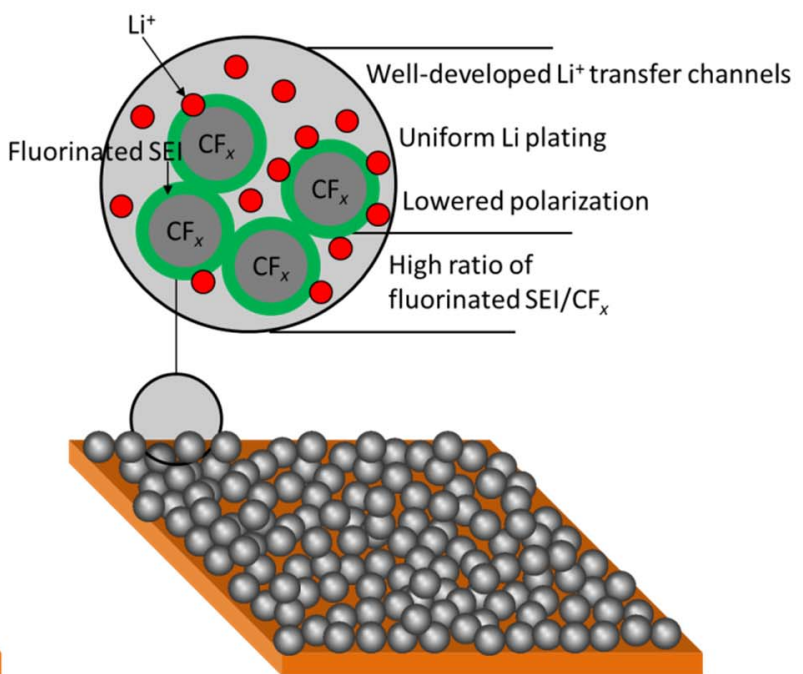

Fig. 1 Schematic representations of (a) large $C_{x}$ flakes based 2D structure and (b) down-sized CF $x$ particles based 3D framework for $\mathrm{Li}$ metal cycling.

microscopy (SEM, FEI, QUATA 250 FEG) under the emission voltage of $5 \mathrm{kV}$, while $10 \mathrm{kV}$ was applied during the measurements of electron dispersive spectrometer (EDS). All the samples were coated with Au thin film to obtain high-quality images. Surface analysis was carried out with an X-ray photoelectron spectrometer (XPS, Axis Ultra DLD), which was excited by $\mathrm{Mg} K_{\alpha}$ radiation source at a constant power of $100 \mathrm{~W}$ $(15 \mathrm{kV}, 6.67 \mathrm{~mA})$. The weight ratio of organic species in the investigated structures were evaluated using Thermo-gravimetry (TG, PerkinElmer Diamond TG/Differential Thermal Analysis (DTA)) on a temperature range of $30-800{ }^{\circ} \mathrm{C}$, with a ramping rate of $10{ }^{\circ} \mathrm{C} \cdot \mathrm{min}^{-1}$ under an argon atmosphere. BrunauerEmmett-Teller (BET) surfaces were obtained through nitrogen gas adsorption measurements with an ASAP2020HD88 analyzer from Micromeritics, Inc.

\subsection{Electrochemical measurements}

2032R coin cells were used for cell assembly. The separator films with a thickness of $20 \mu \mathrm{m}$ were purchased from Celgard, and cut into discs with a diameter of $19 \mathrm{~mm}$, in which $50 \mu \mathrm{L}$ electrolyte of $1 \mathrm{~mol} \cdot \mathrm{L}^{-1} \mathrm{LiPF}_{6}$ in ethylene carbonate (EC) and diethyl carbonate (DEC) $1: 1$ by volume, with $5 \%$ (volume fraction) fluoro-ethylene carbonate (FEC) was added. The $\mathrm{CF}_{x^{-}}$ based structures were prepared by mixing $\mathrm{CF}_{x}$ or $\mathrm{CF}_{x}-400$ : polyvinylidene fluoride (PVDF) at a mass ratio of $8: 2$ in $N$ methyl pyrrolidone (NMP). The slurries were cast onto copper $\mathrm{Cu}$ foils, followed by vacuum drying at $120{ }^{\circ} \mathrm{C}$ for $12 \mathrm{~h}$ to obtain the electrodes. The mass loading of $\mathrm{CF}_{x}$ or $\mathrm{CF}_{x}-400$ is $\sim 5$ $\mathrm{mg} \cdot \mathrm{cm}^{-2}$. Li cycling $\mathrm{CEs}$ on $\mathrm{CF}_{x}$ or $\mathrm{CF}_{x}-400$ structures were assessed in $\mathrm{Li}-\mathrm{Cu}$ cells, by plating $\mathrm{Li}$ at desired current density and capacity followed by stripping Li to a cut-off voltage of 0.5 $\mathrm{V}$ vs $\mathrm{Li} / \mathrm{Li}^{+}$. The $\mathrm{LiFePO}_{4}$ electrodes were obtained by mixing $\mathrm{LiFePO}_{4}$ : Super-P : PVDF ( $8: 1: 1$ by wt.) in NMP. The slurries were cast on aluminum foils, followed by vacuum drying at $120{ }^{\circ} \mathrm{C}$ for $12 \mathrm{~h}$. The capacity loading of the obtained $\mathrm{LiFePO}_{4}$ cathode is $\sim 0.85 \mathrm{mAh} \cdot \mathrm{cm}^{-2}\left(170 \mathrm{mAh} \cdot \mathrm{g}^{-1}\right)$. The $\mathrm{Li}-\mathrm{LiFePO}_{4}$ cells were cycled between 2.5 and $4.4 \mathrm{~V}$ vs $\mathrm{Li} / \mathrm{Li}^{+}$with charge/discharge rates of $0.5 C / 0.5 C$. The anodes used in $\mathrm{Li}$ $\mathrm{LiFePO}_{4}$ cells were bare $\mathrm{Cu}$ or $\mathrm{CF}_{x}-400$ on which $2.5 \mathrm{mAh} \cdot \mathrm{cm}^{-2}$ Li was pre-deposited (corresponding to a negative/positive capacity, N/P ratio 3), denoted as $\mathrm{Cu} @ \mathrm{Li}$ and $\mathrm{CF}_{x}-400 @ \mathrm{Li}$, respectively. It should be mentioned that 10 cycles of discharge/charge process between $0-1 \mathrm{~V} v s \mathrm{Li} / \mathrm{Li}^{+}$at a current density of $0.5 \mathrm{~mA} \cdot \mathrm{cm}^{-2}$ were applied to the $\mathrm{CF}_{x}-400$ electrode to complete the formation of the inner $\mathrm{Li}^{+}$conducting channels prior to the fabrication of composite anode. The electrochemical impedance spectroscopy (EIS) spectra were measured using a potentiostat/galvanostat $1470 \mathrm{E}$ equipped with a frequency response analyzer 1455A from Solartron. The EIS measurements were performed under potentiostatic mode, from $1 \times 10^{5}$ to $1 \times$ $10^{-1} \mathrm{~Hz}$ with a voltage perturbation of $5 \mathrm{mV}$.

\section{Results and discussion}

The morphology of $\mathrm{CF}_{x}$ flakes is shown in Fig. 2a, with a typical size of dozens of micrometers. An evident down-sized morphology was observed for $\mathrm{CF}_{x}-400$ particles, which are ranged on 1-2 $\mu \mathrm{m}$ (Fig. 2b). The down-sizing of $\mathrm{CF}_{x}$ also involved the increased BET surface, which is $\sim 196.84 \mathrm{~m}^{2} \cdot \mathrm{g}^{-1}$ for $\mathrm{CF}_{x}-400$, compared to $\sim 156.78 \mathrm{~m}^{2} \cdot \mathrm{g}^{-1}$ for $\mathrm{CF}_{x}$ (Fig. S1b, Supporting Information). It should be mentioned that the sharply changed morphologies from $\mathrm{CF}_{x}$ to $\mathrm{CF}_{x}-400$ do not affect their crystal structures and chemical compositions, as shown by their quasi-identical XRD patterns (Fig. Sla, Supporting Information), similar mass ratio of $\mathrm{F}$ element $(\sim 60 \%)$ on the $\mathrm{C}$ and F overlapped uniform surfaces (Table S1, Figs. S2a and S2b, Supporting Information). XPS wide scans indicate that $\mathrm{C}$ and $\mathrm{F}$ are the main elements on pristine $\mathrm{CF}_{x}$ and $\mathrm{CF}_{x}-400$ except some traces of $\mathrm{O}$ impurities (Fig. S3a, Supporting Information), and obvious peaks of $-\mathrm{CF}(688.6 \mathrm{eV}), \mathrm{C}-\mathrm{C}(284.6 \mathrm{eV}), \mathrm{C}-\mathrm{CF}_{2}$ 
(a)

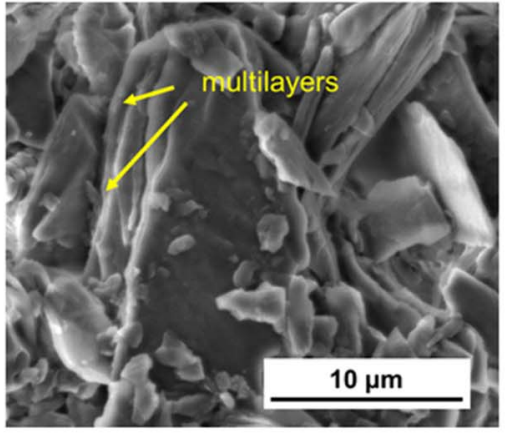

(b)

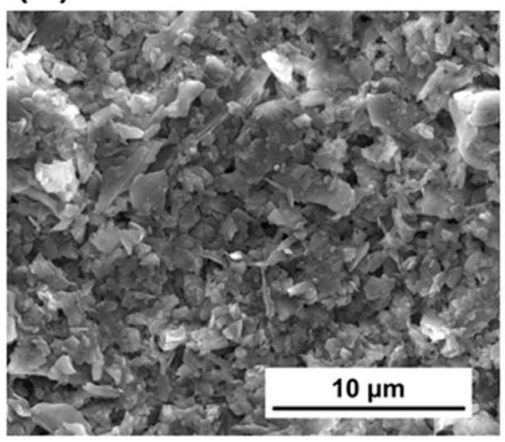

(c)

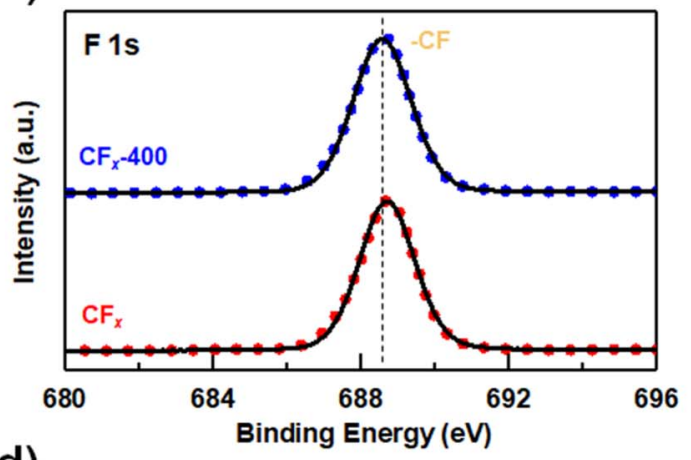

(d)

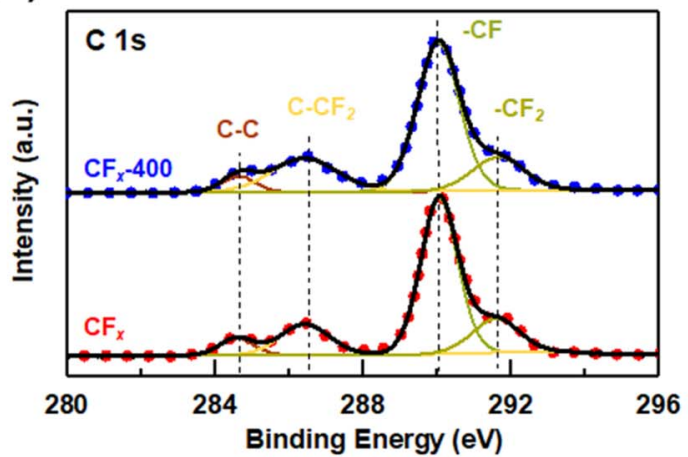

Fig. 2 SEM images of pristine (a) $\mathrm{CF}_{x}$ and (b) $\mathrm{CF}_{x}-400$; (c) F $1 s$ and (d) C $1 s$ XPS spectra of pristine CF $\mathrm{CF}_{x}$ and $\mathrm{CF}_{x}-400$.

(286.5 eV), $-\mathrm{CF}(290.1 \mathrm{eV})$ and $-\mathrm{CF}_{2}(291.6 \mathrm{eV})$ are observed on the amplified $\mathrm{F} 1 s$ and $\mathrm{C} 1 s$ spectra (Figs. $2 \mathrm{c}$ and $2 \mathrm{~d}$ ). Thus, the $\mathrm{CF}_{x}$ and $\mathrm{CF}_{x}-400$ based structures could be used as very representative model structures to assess the down-sizing effect of $\mathrm{CF}_{x}$ on the protection of Li metal anodes.

As above-mentioned, the down-sized $\mathrm{CF}_{x}-400$ particles are expected to form a framework in which fast $\mathrm{Li}^{+}$conducting channels are formed. To assess the latter, $\mathrm{CF}_{x}$ and $\mathrm{CF}_{x}-400$ based electrodes were fabricated via doctor blade coating of $\mathrm{CF}_{x}$ :PVDF and $\mathrm{CF}_{x}-400$ :PVDF mixtures on $\mathrm{Cu}$ foils, which were subjected to lithiation process down to $0 \mathrm{~V} v s \mathrm{Li} / \mathrm{Li}^{+}$(Fig. 3a and Table S2, Supporting Information). For $\mathrm{CF}_{x}$, a specific capacity of 1.16 $\mathrm{mAh} \cdot \mathrm{mg}^{-1} \mathrm{Li}$ was achieved at $0 \mathrm{~V} v s \mathrm{Li} / \mathrm{Li}^{+}$, corresponding to the formation of SEI layers and lithiation of $\mathrm{CF}_{x}$ flakes. Meanwhile a higher specific capacity of $1.64 \mathrm{mAh} \cdot \mathrm{mg}^{-1} \mathrm{Li}$ was achieved for $\mathrm{CF}_{x}-400$, whereas the additional capacity contribution should arise from the formation of $\mathrm{Li}^{+}$conducting channels in the framework consisted of down-sized $\mathrm{CF}_{x}-400$ particles. The lithiation capacities for thinner $\mathrm{CF}_{x}$ and $\mathrm{CF}_{x}-400$ with a mass loading $\sim 1 \mathrm{mg} \cdot \mathrm{cm}^{-2}$ were also compared. As shown in Fig. S4 (Supporting Information), similar lithiation capacities were obtained, which were $\sim 1.24$ and $\sim 1.78 \mathrm{mAh} \cdot \mathrm{g}^{-1}$ for $\mathrm{CF}_{x}$ and $\mathrm{CF}_{x}-400$, respectively, showing the intrinsic lithiation capacities for these $\mathrm{CF}_{x}$ materials. The formation of $\mathrm{Li}^{+}$conduction channels in the $\mathrm{CF}_{x}-400$ framework was further demonstrated by TG measurements, whereas the TG curves of the lithiated $\mathrm{CF}_{x}$ and $\mathrm{CF}_{x}-400$ showed the continuous weight loss from the initial stage of temperature ramping, while the weight loss of pristine $\mathrm{CF}_{x}$ and $\mathrm{CF}_{x}-400$ powders only take place above $400{ }^{\circ} \mathrm{C}$ (Fig.
S5, Supporting Information). These results show that the weight loss occurring at early stage of TG measurements (below $400{ }^{\circ} \mathrm{C}$ ) for the lithiated $\mathrm{CF}_{x}$ and $\mathrm{CF}_{x}-400$ should arise from the organic species in the SEI layers and/or $\mathrm{Li}^{+}$conducting channels. Furthermore, a weight loss of $\sim 18 \%$ was observed for the lithiated $\mathrm{CF}_{x}-400$ electrode, while it was only $\sim 9 \%$ for the lithiatied $\mathrm{CF}_{x}$ (Fig. 3b). Since the weight ratio and absolute quantity of $\mathrm{CF}_{x}$ and $\mathrm{CF}_{x}-400$ in the coating slurry mixtures were strictly fixed at the same values, the higher weight loss observed on the TG curves should arise from the formation of the inner $\mathrm{Li}^{+}$conducting channels including partially organic species in the $\mathrm{CF}_{x}-400$ framework.

The morphologies of lithiated $\mathrm{CF}_{x}$ and $\mathrm{CF}_{x}-400$ are shown in Fig. 3c, d, and Fig. S6a, S6b (Supporting Information). Evident cracks and pulverizations are observed on $\mathrm{CF}_{x}$ flakes (Figs. 3c and S6a (Supporting Information)), depicting their structural instability during lithiation and eventual collapse for further $\mathrm{Li}$ deposition. The amplified SEM images of pristine and lithiated $\mathrm{CF}_{x}$ flakes are shown in Fig. S7 (Supporting Information), whereas evident cracks could be observed on the lithiated flake surfaces, which are mainly caused by the strain rooted in the lithation process. This feature further demonstrates the necessity of down-sizing the $\mathrm{CF}_{x}$ particles to mitigate the deformation caused by mechanical strain during lithiation process. In contrast, intact structure is maintained for the $\mathrm{CF}_{x}-400$ framework (Figs. 3d and S6b(Supporting Information)), indicating that the initial lithiation was mainly rooted in the formation of $\mathrm{Li}^{+}$conducting channels without affecting the overall structure of the framework, which are beneficial to 

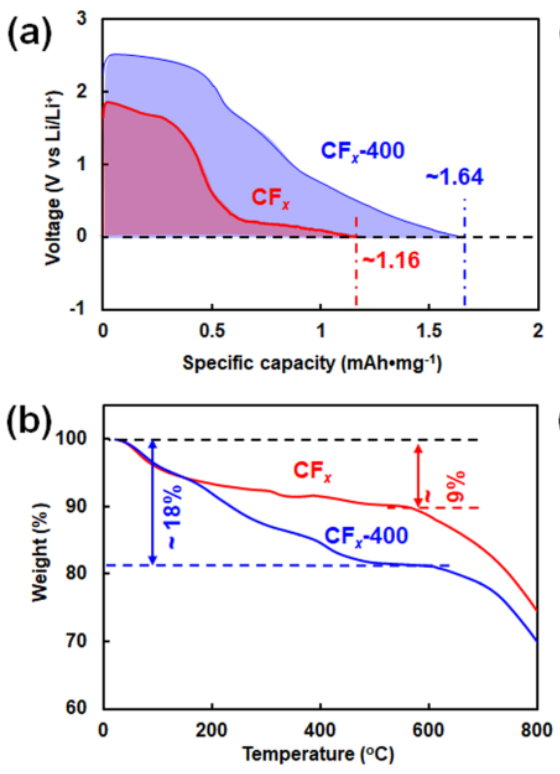

(c)

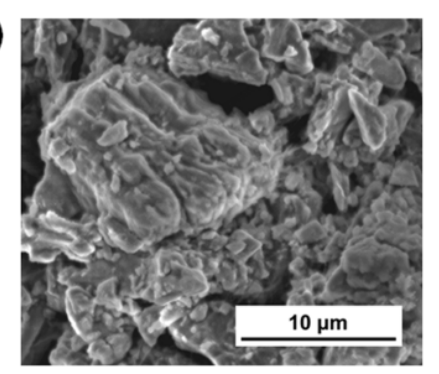

(d)

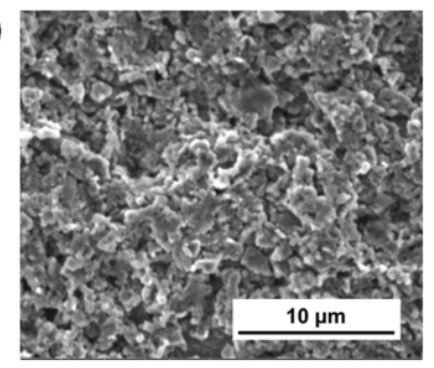

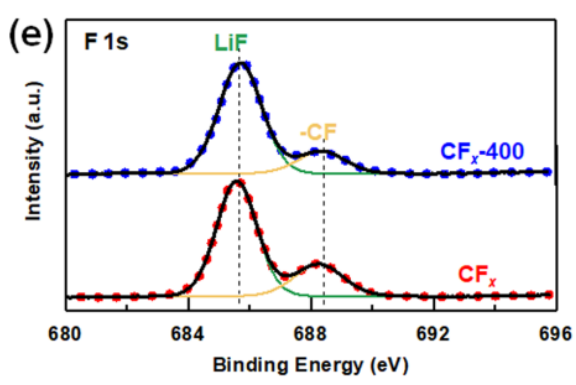

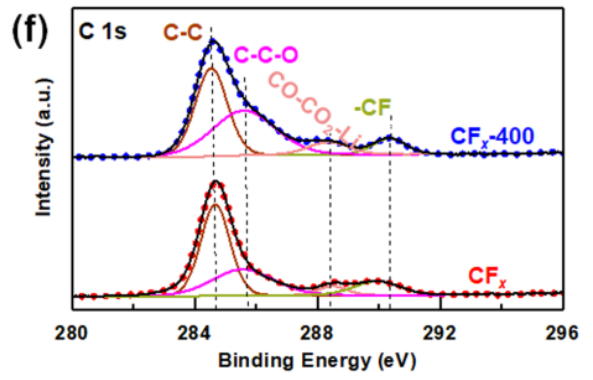

Fig. 3 (a) The 1st discharge curves of $C F_{x}$ and $C F_{x}-400$ with a mass loading $\sim 1 \mathrm{mg} \cdot \mathrm{cm}^{-2}$; (b) TG curves of lithiated $C F_{x}$ and $C F_{x}-400$; SEM images of lithiated (c) $C F_{x}$ and (d) $C F_{x}-400$; (e) F $1 s$ and (f) C 1s XPS spectra of lithiated $C F_{x}$ and $C F_{x}-400$.

enable uniform Li deposition in subsequent cycling. The surface components of the lithiated electrodes were analyzed by EDS and XPS, showing similar chemical compositions with coexistence of C, O and F elements (Table S1, Fig. S2c, S2d and $\mathrm{S} 3 \mathrm{~b}$, Supporting Information). Besides $\mathrm{C}$ and $\mathrm{F}$, the presence of $\mathrm{O}$ should arise from the solvent decompositions. On the F $1 s$ XPS spectra, in addition to the peak of $-\mathrm{CF}(688.5 \mathrm{eV})$, the peak of $\mathrm{LiF}(685.5 \mathrm{eV})$ appeared (Fig. 3e), indicating the conversion of $\mathrm{CF}_{x}$ into $\mathrm{LiF}$ during the lithiation process. It should be mentioned that FEC from the electrolyte could also be reductively decomposed into $\mathrm{LiF}^{21}$, thus a FEC-free electrolyte (1 $\mathrm{mol} \cdot \mathrm{L}^{-1} \mathrm{LiPF}_{6}$ in $\mathrm{EC}: \mathrm{DEC} 1: 2$ by vol.) was used to perform the lithiation of $\mathrm{CF}_{x}$ and $\mathrm{CF}_{x}-400$. As shown in Fig. S8, Supporting Information, evident peaks of $\mathrm{LiF}$ were clearly observed for both $\mathrm{CF}_{x}$ and $\mathrm{CF}_{x}-400$, demonstrating the formation of $\mathrm{LiF}$ through the lithiation of $\mathrm{CF}_{x}$ materials. Meanwhile, the formations of organic species are observed on $\mathrm{C} 1 \mathrm{~s}$ spectra, shown by the peaks of $\mathrm{C}-\mathrm{C}-\mathrm{O}(285.6 \mathrm{eV})$ and $\mathrm{CO}-\mathrm{CO}_{2} \mathrm{Li}$ $(288.4 \mathrm{eV})$ which should correspond to the organic species included in the SEI layers on $\mathrm{CF}_{x}$ or in the $\mathrm{Li}^{+}$conducting channels in $\mathrm{CF}_{x}-400$.

Based on the above results, it can be concluded that the solvent decompositions and conversions of $\mathrm{CF}_{x}$ into $\mathrm{LiF}$ occurred during the lithiation processes of $\mathrm{CF}_{x}$ and $\mathrm{CF}_{x}-400$, leading to the formation of LiF-imbedded SEI layers on the $\mathrm{CF}_{x}$ flakes or LiFincorporated $\mathrm{Li}^{+}$conducting channels in the $\mathrm{CF}_{x}-400$ framework. Meanwhile the higher content of organic species from the $\mathrm{Li}^{+}$ conducting channels (weight loss on TG curves, Fig. 3b) can maintain the integrity of the $\mathrm{CF}_{x}-400$ framework as a stable host to accommodate $\mathrm{Li}$ deposition. It should be mentioned that the $\mathrm{CF}_{x}$ materials have a low electronic conductivity, while no electronic conductive agents were added into the $\mathrm{CF}_{x}-400$ framework. However, the latter could be a beneficial feature that forces the initial $\mathrm{Li}$ deposition to occur in the bottom of the framework whereas the reduction into $\mathrm{Li}$ metal could be achieved by receiving the electrons from the current collector, and this initially deposed Li layer could further serve as electron conductor for subsequent Li deposition that progressively fills the void space of the framework. Based on the synergism of the LiF-incorporated $\mathrm{Li}^{+}$conducting channels and down-sized $\mathrm{CF}_{x}-$ 400 particles, the stability of Li metal cycling could be much improved in the $\mathrm{CF}_{x}-400$ framework, as shown in the following paragraph.

The EIS measurements were conducted to assess the interfacial stability of $\mathrm{Li}-\mathrm{Cu}$ cells using bare $\mathrm{Cu}, \mathrm{CF}_{x}$ or $\mathrm{CF}_{x}-400$ coated $\mathrm{Cu}$ as working electrodes. Before cycling, large impedances were observed for all the samples due to the lack of $\mathrm{Li}^{+}$conducting interphase (Fig. 4a). After the formations of SEI layers by cycling the $\mathrm{Li}-\mathrm{Cu}$ cells for 10 cycles, the typical semicycles representing the interfacial impedances were clearly observed for all the samples, which are 33.57, 134.64 and $45 \Omega$ for bare $\mathrm{Cu}, \mathrm{CF}_{x}$ and $\mathrm{CF}_{x}-400$, respectively (Fig. 4b). Herein, the interfacial impedances of $\mathrm{CF}_{x}$ and $\mathrm{CF}_{x}-400$ are higher than that of bare $\mathrm{Cu}$, indicating that these artificial structures engender unavoidable additional impedances to the interfacial charge transfer. It should be mentioned that the bulk electronic conductivity of fluorocarbon is depending on the fluorination degree, higher the fluorination degree, lower the electronic conductivity. In the present case, the F content is above $50 \%$, leading to relatively poor electronic conductivity. However, the $\mathrm{CF}_{x}$-400 framework exhibits much smaller interfacial impedance increase, thanks to the well cross-linked $\mathrm{Li}^{+}$conducting channels. After 30 cycles, the interfacial impedances were increased to 60.86 and $157.09 \Omega$ for bare $\mathrm{Cu}$ and $\mathrm{CF}_{x}$, respectively, while it was stably maintained at $\sim 45 \Omega$ for $\mathrm{CF}_{x}$ 400 (Fig. 4c). These results depict the serious side product 
(a)
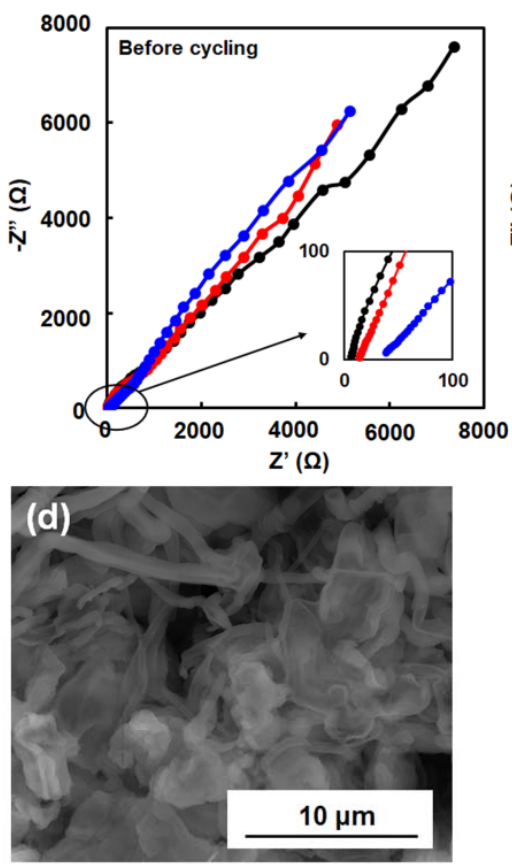

(g)

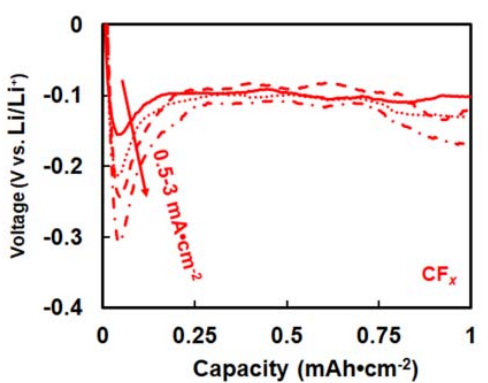

(b)
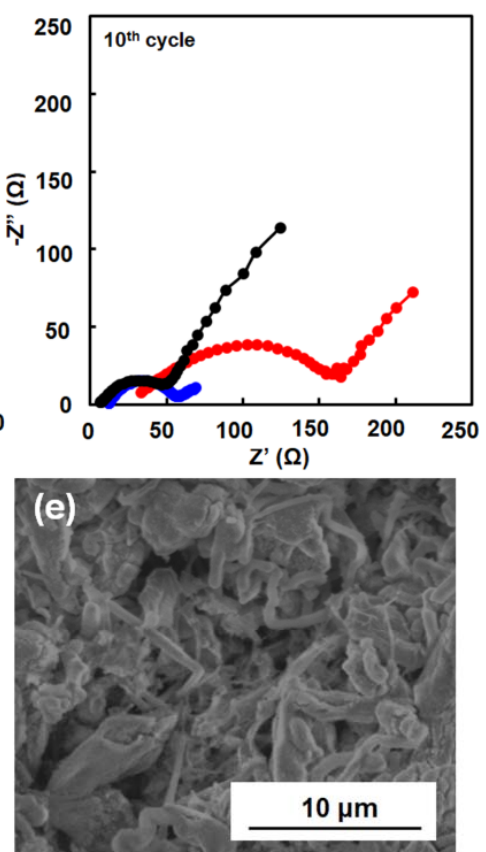

(h)

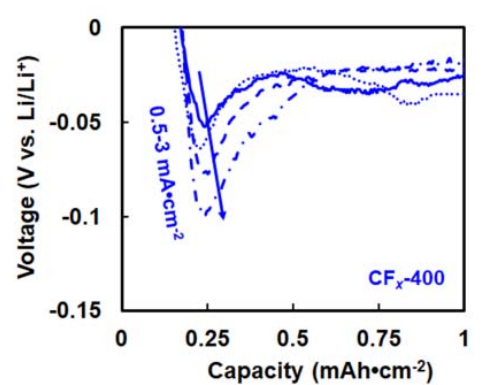

(c)
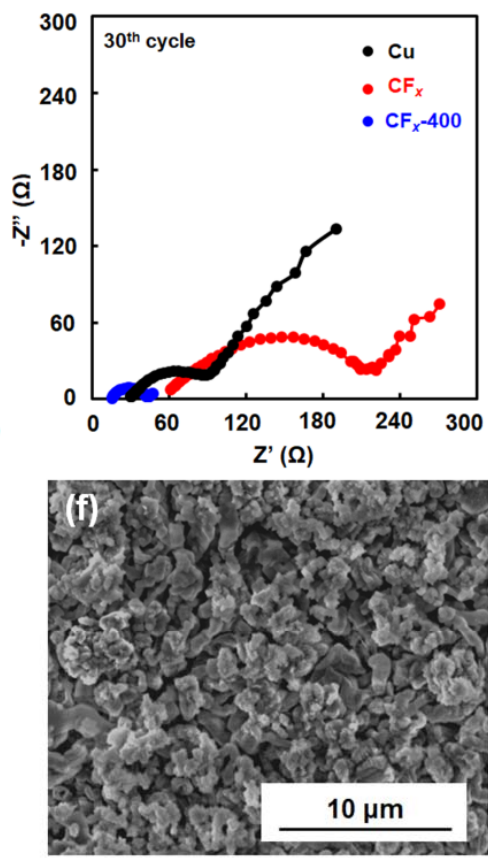

(i)

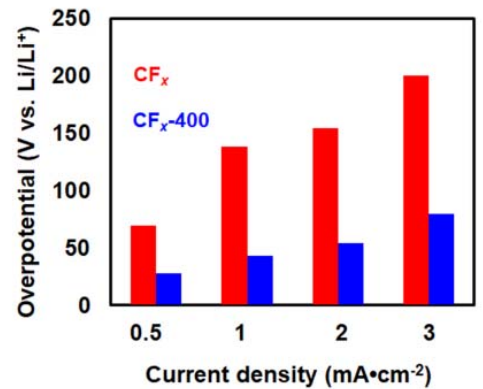

Fig. 4 Nyquist plots of $\mathrm{Cu}, \mathrm{CF}_{x}$ and $\mathrm{CF}_{x}-400$ electrodes (a) before cycling, at the (b) 10th and (c) 30th cycles; SEM photos of (d) Cu, (e) CF $x$ and (f) $\mathrm{CF}_{x}-400$ electrodes after 30 cycles of $1 \mathrm{mAh} \cdot \mathrm{cm}^{-2} \mathrm{Li}$ plating/stripping; (g, h) typical voltage profiles of Li plating on (g) CF $x$ and

(h) $\mathrm{CF}_{x}-400$ at 0.5, 1, 2 and $3 \mathrm{~mA} \cdot \mathrm{cm}^{-2}$; (i) nucleation overpotentials of Li plating on $\mathrm{CF}_{x}$ and $\mathrm{CF}_{x}-400$ at $0.5,1,2$ and $3 \mathrm{~mA} \cdot \mathrm{cm}^{-2}$.

accumulations on bare $\mathrm{Cu}$ and $\mathrm{CF}_{x}$ upon cycling, which were further confirmed by their SEM images, showing tremendous dendritic deposits (Fig. 4d, e). Although the LiF-imbedded SEI layers were revealed as optimized surface layers to improve the cycling stability of Li metal anodes, the present results show that the lack of $\mathrm{Li}^{+}$conducting channels still hinders uniform deposition on the $2 \mathrm{D} \mathrm{CF}_{x}$ flakes. In contrast, an intact surface was kept for the $\mathrm{CF}_{x}-400$ framework (Fig. 4f), depicting uniform $\mathrm{Li}$ plating/stripping occurring in this optimal structure, consistent to the stabilized interfacial impedances as abovedemonstrated.

The measurements of interfacial impedances and $\mathrm{Li}$ deposition morphologies indicate a much improved $\mathrm{Li}^{+}$transfer kinetic on $\mathrm{CF}_{x}-400$. To address the latter, the $\mathrm{Li}$ nucleation overpotentials on $\mathrm{CF}_{x}$ and $\mathrm{CF}_{x}-400$ were assessed by measuring the voltage profiles of Li plating at $0.5,1,2$ and $3 \mathrm{~mA} \cdot \mathrm{cm}^{-2}$, as shown in Fig. 4g, h. The as-obtained Li nucleation overpotentials (the difference between the voltage tip and plateau) are 69.1, 138.4, 154.6 and $200.2 \mathrm{mV}$ for $\mathrm{CF}_{x}$ at $0.5,1,2$ and $3 \mathrm{~mA} \cdot \mathrm{cm}^{-2}$, respectively, and 27.8, 43.0, 54.1 and $79.4 \mathrm{mV}$ for $\mathrm{CF}_{x}-400$ at $0.5,1,2$ and $3 \mathrm{~mA} \cdot \mathrm{cm}^{-2}$, respectively (Fig. 4i). Thus, for a given current density, the nucleation overpotential on $\mathrm{CF}_{x}-400$ is only $30 \%-40 \%$ of that on $\mathrm{CF}_{x}$. These results clearly indicate the much improved $\mathrm{Li}^{+}$transfer kinetic in the $\mathrm{CF}_{x}-400$ framework.

The Li plating/stripping morphologies were systematically carried out at various areal capacities, as shown in Fig. 5. Despite the presence of $\mathrm{LiF}$ in the formed SEI layer, dendritic morphologies were still observed for $\mathrm{Li}$ plating up to 8 $\mathrm{mAh} \cdot \mathrm{cm}^{-2}$ on $\mathrm{CF}_{x}$ (Fig. 5a), indicating the sluggish $\mathrm{Li}^{+}$transfer on the large $\mathrm{CF}_{x}$ flakes. Furthermore, the evidence of side products formed on $\mathrm{CF}_{x}$ could be revealed by the remaining filament species after Li stripping process to $0 \mathrm{mAh} \cdot \mathrm{cm}^{-2}$, whereas serious accumulation of side products was observed (Fig. 5a). In sharp contrast, noodle-like deposits were observed for $\mathrm{Li}$ plating on $\mathrm{CF}_{x}-400$, whereas the sizes of deposits increased with the areal capacity (Fig. 5b), leading to the lowsurface-area contact with electrolyte and reduced side reactions. The rounded Li deposits could also reduce the probability of 
(a)
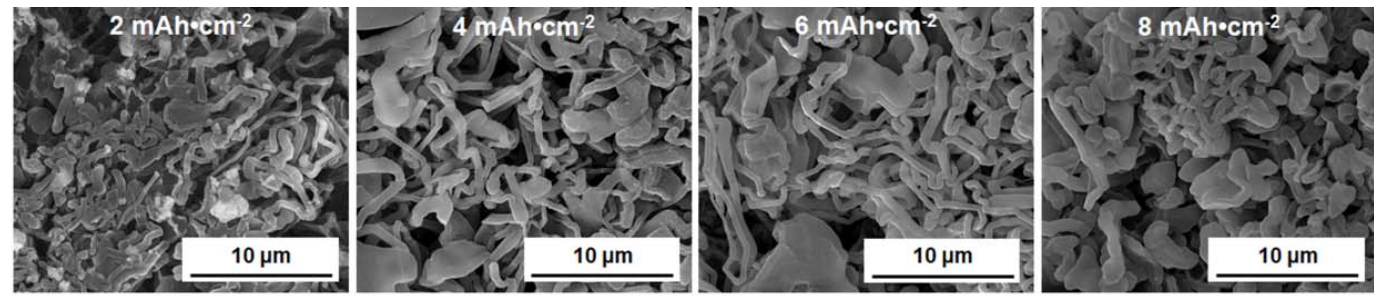

Li plating

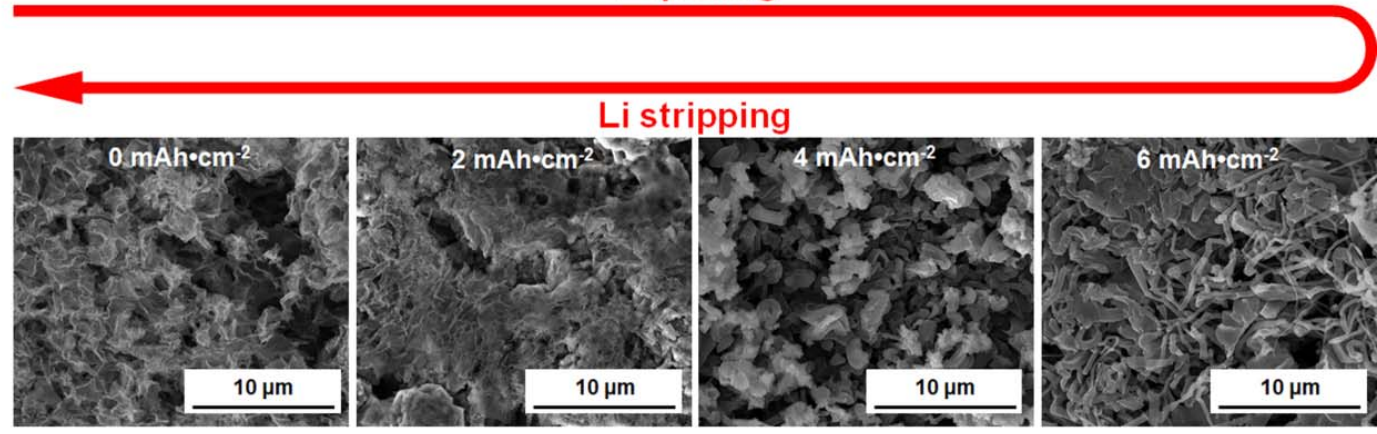

(b)
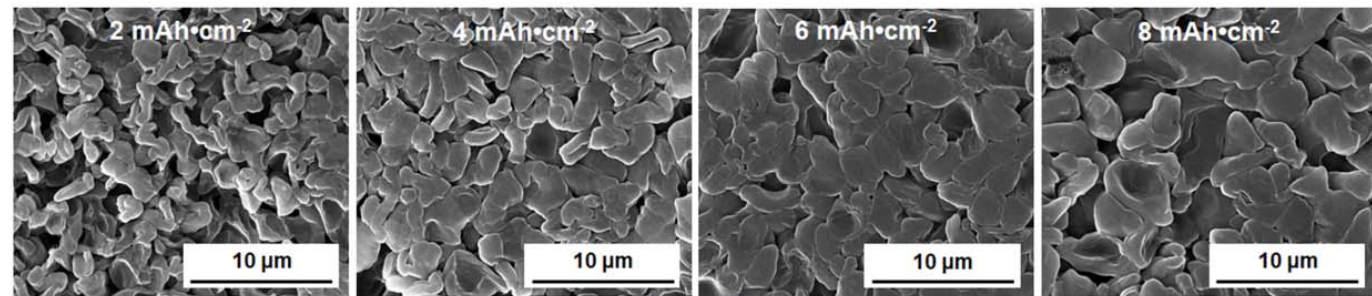

Li plating

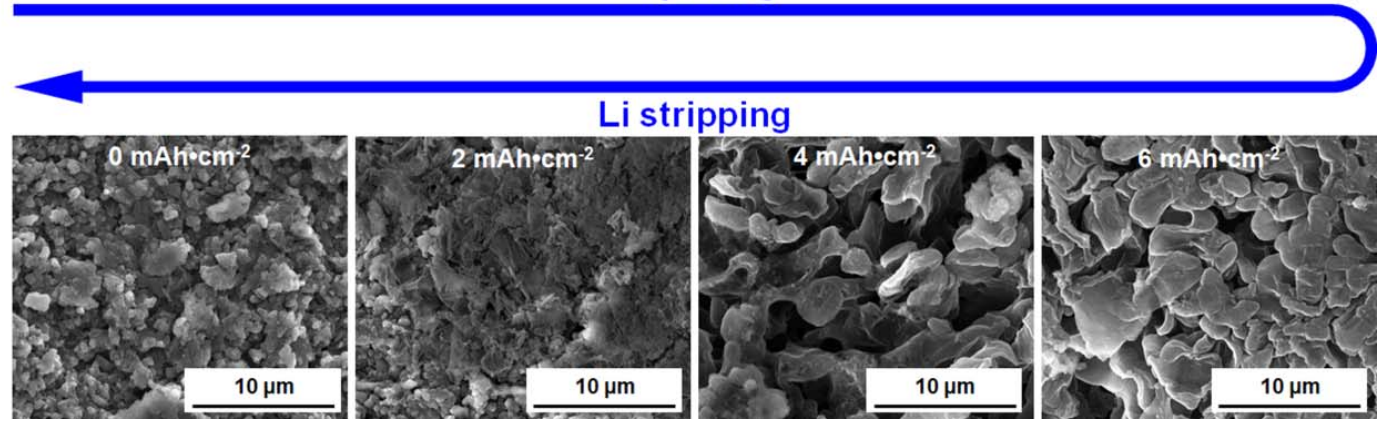

Fig. $5 \mathrm{Li}$ plating/stripping morphologies at various areal capacities on (a) $\mathrm{CF}_{x}$ and (b) $\mathrm{CF}_{x}-400$.

piercing the separator and improve the safety of LMBs. Furthermore, the intact surface morphology was observed after $\mathrm{Li}$ stripping process to $0 \mathrm{mAh} \cdot \mathrm{cm}^{-2}$, demonstrating the significantly suppressed side reactions for Li plating on $\mathrm{CF}_{x}-400$. These results clearly indicate the greatly improved $\mathrm{Li}^{+}$transfer kinetic in the $\mathrm{CF}_{x}-400$ framework.

The cycling stability of $\mathrm{Li}$ metal anodes on bare $\mathrm{Cu}, \mathrm{CF}_{x}$ and $\mathrm{CF}_{x}-400$ were assessed in $\mathrm{Li}-\mathrm{Cu}$ cells. Fig. $6 \mathrm{a}$ shows the cycling performances at a current density of $0.5 \mathrm{~mA} \cdot \mathrm{cm}^{-2}$ for a fixed capacity of $1 \mathrm{mAh} \cdot \mathrm{cm}^{-2}$. Initial lithiation processes were clearly observed for $\mathrm{CF}_{x}$ and $\mathrm{CF}_{x}-400$, leading to progressive increases of CEs during initial cycling. These processes are believed to undergo the formation of LiF-imbedded SEI layers on $\mathrm{CF}_{x}$ flakes or $\mathrm{LiF}$-incorporated $\mathrm{Li}^{+}$conducting channels in $\mathrm{CF}_{x}-400$ framework. Posterior to the lithiation processes, more stable cycling were achieved for $\mathrm{CF}_{x}$ ( $\sim 80$ cycles $)$ and $\mathrm{CF}_{x}-400(\sim 240$ cycles), compared to that on bare $\mathrm{Cu}$ ( $\sim 40$ cycles), whereas the outstanding performances of $\mathrm{CF}_{x}-400$ further demonstrate the synergism of fluorinated sites and fast $\mathrm{Li}^{+}$conducting channels for stable $\mathrm{Li}$ plating/stripping. Consistently, much more stabilized Li plating/stripping curves were maintained for $\mathrm{CF}_{x}$ 400 upon cycling (Fig. 6d), while clear polarization enlargement and capacity fading were observed for bare $\mathrm{Cu}$ (Fig. 6b) and $\mathrm{CF}_{x}$ (Fig. 6c). The cycling voltage hysteresis in the condition of 0.5 $\mathrm{mA} \cdot \mathrm{cm}^{-2}-1 \mathrm{mAh} \cdot \mathrm{cm}^{-2}$ are shown in Fig. $6 \mathrm{~g}$, whereas the polarization of $\mathrm{CF}_{x}$ (from $180.7 \mathrm{mV}$ at the 10th cycle to 217.0 $\mathrm{mV}$ at the 50th cycle) was larger than those of bare $\mathrm{Cu}$ (from $78.1 \mathrm{mV}$ at the 5th cycle to $159.6 \mathrm{mV}$ at the 50th cycle) and $\mathrm{CF}_{x^{-}}$ 400 (stably below $80 \mathrm{mV}$ ), showing the serious drawbacks of limited $\mathrm{Li}^{+}$transfer paths and low electronic conductivity of $\mathrm{CF}_{x}$ flakes. Although low polarization was initially achieved on bare $\mathrm{Cu}$, the fast increase of voltage hysteresis during subsequent cycling still indicates large accumulation of side products, consistent to the results of EIS and SEM (Figs. 4 and 5). 

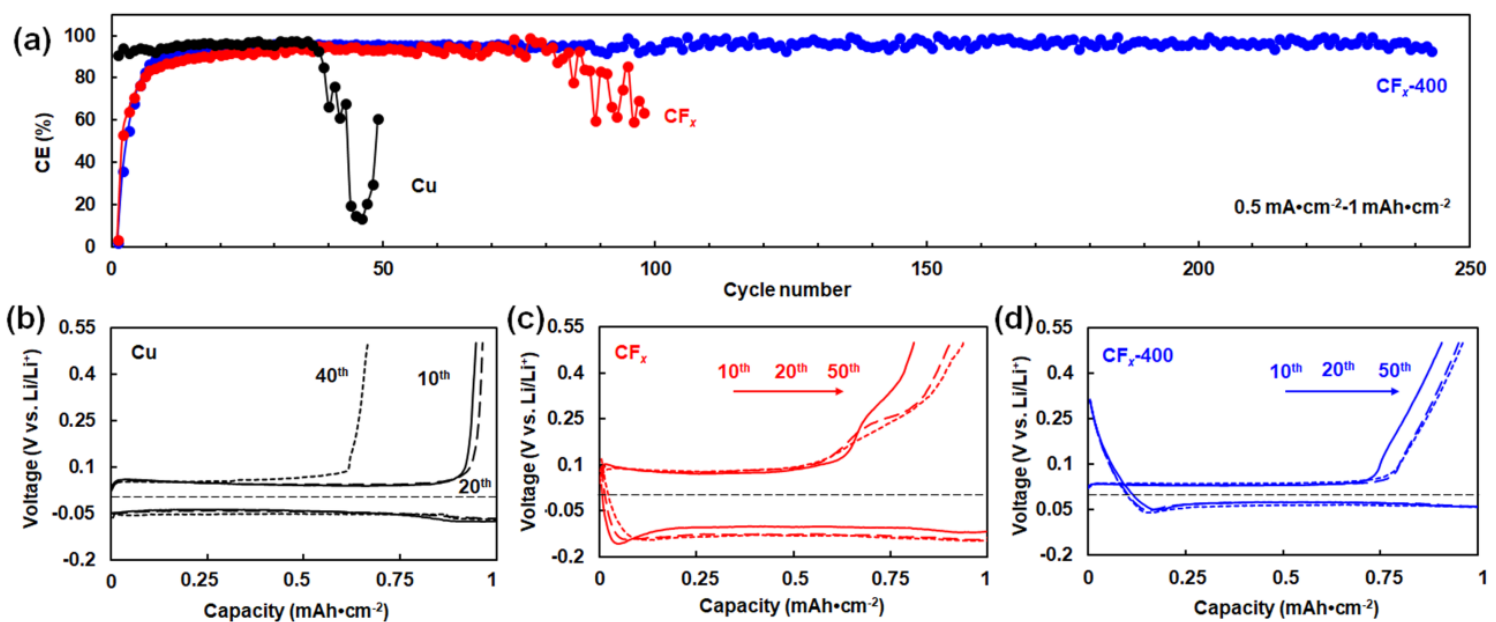

(e)
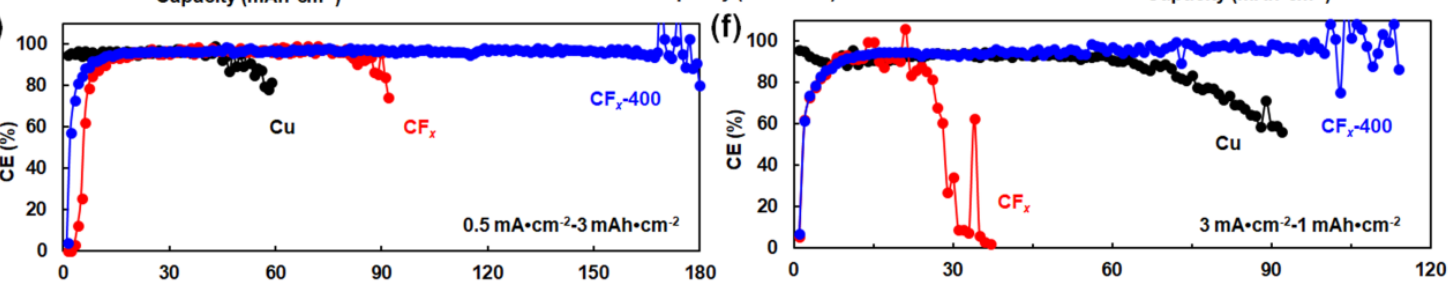

(g)

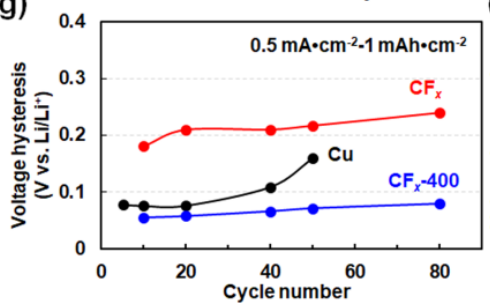

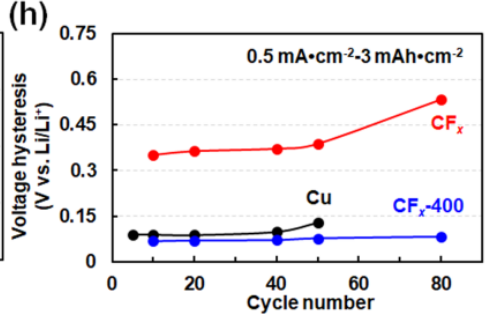

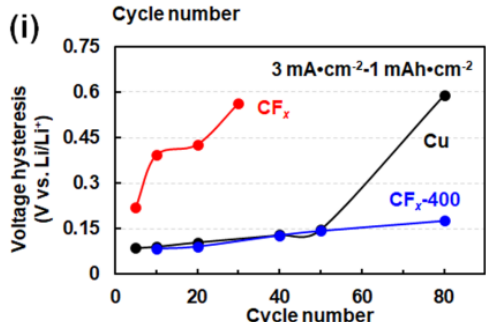

Fig. 6 (a) Cycling stability of $\mathrm{Li}$ metal anodes on $\mathrm{Cu}, \mathrm{CF}_{x}$ and $\mathrm{CF}_{x}-400$ electrodes at $0.5 \mathrm{~mA} \cdot \mathrm{cm}^{-2}-1 \mathrm{mAh} \cdot \mathrm{cm}^{-2}$, and $\mathrm{charge}-\mathrm{discharge} \mathrm{curves}$ of

(b) $\mathrm{Cu}$, (c) $\mathrm{CF}_{x}$ and (d) $\mathrm{CF}_{x}-400$ electrodes upon cycling at $0.5 \mathrm{~mA} \cdot \mathrm{cm}^{-2}-1 \mathrm{mAh} \cdot \mathrm{cm}^{-2}$; cycling stability of Li metal anodes on $\mathrm{Cu}, \mathrm{CF} x$ and

$\mathrm{CF}_{x}-400$ electrodes at (e) $0.5 \mathrm{~mA} \cdot \mathrm{cm}^{-2}-3 \mathrm{mAh} \cdot \mathrm{cm}^{-2}$ and (f) $3 \mathrm{~mA} \cdot \mathrm{cm}^{-2}-1 \mathrm{mAh} \cdot \mathrm{cm}^{-2}$; voltage hysteresis of $\mathrm{Li}$ plating/stripping on Cu, CF $x$ and $\mathrm{CF}_{x}-400$ electrodes at (g) $0.5 \mathrm{~mA} \cdot \mathrm{cm}^{-2}-1 \mathrm{mAh} \cdot \mathrm{cm}^{-2}$, (h) $0.5 \mathrm{~mA} \cdot \mathrm{cm}^{-2}-3 \mathrm{mAh} \cdot \mathrm{cm}^{-2}$ and (i) $3 \mathrm{~mA} \cdot \mathrm{cm}^{-2}-1 \mathrm{mAh} \cdot \mathrm{cm}^{-2}$.

The great Li protection ability of $\mathrm{CF}_{x}-400$ framework was also proved for higher current density and capacity. For cycling in high capacity condition of $0.5 \mathrm{~mA} \cdot \mathrm{cm}^{-2}-3 \mathrm{mAh} \cdot \mathrm{cm}^{-2}$, stable CEs were maintained for $\mathrm{CF}_{x}-400$ over 160 cycles (Fig. 6e, h), showing its ability to accommodate high-loading Li plating/ stripping which is expected in practical application. For cycling in high current density condition of $3 \mathrm{~mA} \cdot \mathrm{cm}^{-2}-1 \mathrm{mAh} \cdot \mathrm{cm}^{-2}$, a stable cycling of 100 cycles was still obtained for $\mathrm{CF}_{x}-400$ (Fig. 6f), with m oderately maintained polarization (from $\sim 84.9 \mathrm{mV}$ at the 10 th cycle to $\sim 176.2 \mathrm{mV}$ at the 80 th cycle, Fig. 6i). In sharp contrast, very large polarization and poor cycling were observed for $\mathrm{CF}_{x}$ in the same condition (Fig. 6f, i), indicating the sluggish charge transfer through the $2 \mathrm{D} \mathrm{CF}_{x}$-based structure. Besides, the $\mathrm{CF}_{x}$ materials are well-known as a poor electronic conductor, which results in the high polarization of the substrate consisted of large $\mathrm{CF}_{x}$ flakes, as shown by the EIS and voltage hysteresis results (Fig. 4b, c and 6g-i). However, due to the significant content of $\mathrm{LiF}$ generated during the initial lithiation of $\mathrm{CF}_{x}$ (Fig. 3e and S8, Supporting Information), which could serve as the prominent SEI component to protect the deposed Li metal, the substrate of large $\mathrm{CF}_{\mathrm{x}}$ flakes could still exhibit better Li metal cycling than that on bare $\mathrm{Cu}$ at a relatively low current density of $0.5 \mathrm{~mA} \cdot \mathrm{cm}^{-2}$. However, the increase of polarization on the large $\mathrm{CF}_{x}$ flakes became serious at the current density of 3 $\mathrm{mA} \cdot \mathrm{cm}^{-2}$, leading to the Li metal cycling which was even poorer than that on bare $\mathrm{Cu}$. These results further demonstrate the advantage of the framework based on the down-sized $\mathrm{CF}_{x}-400$ particles, which exhibited stable Li metal cycling even at high current densities due to the well-established $\mathrm{Li}^{+}$conducting channels that neutralize the effect of poor electronic conductivity of $\mathrm{CF}_{x}$ materials.

Based on the good $\mathrm{Li}$ protection ability of $\mathrm{CF}_{x}-400$, its application in $\mathrm{Li}_{-}-\mathrm{LiFePO}_{4}$ full cells was also studied. Prior to the assemble of full cell, the $\mathrm{CF}_{x}-400$ coated $\mathrm{Cu}$ electrode was precycled in the $\mathrm{Li}-\mathrm{Cu}$ cell for 10 cycles to complete the lithiation process and form $\mathrm{Li}^{+}$conducting channels, as described in experimental section. $2.5 \mathrm{mAh} \cdot \mathrm{cm}^{-2} \mathrm{Li}$ was then plated on the lithiated $\mathrm{CF}_{x}-400$ framework to form the composite anode (denoted as $\mathrm{CF}_{x}-400 @ \mathrm{Li}$ ), leading to a N/P ratio about 3, which is comparable to the practical condition. As comparison, a $\mathrm{Cu} @ \mathrm{Li}$ anode by plating $2.5 \mathrm{mAh} \cdot \mathrm{cm}^{-2} \mathrm{Li}$ on bare $\mathrm{Cu}$ was also fabricated. Fig. 7a shows the performances of the investigated 

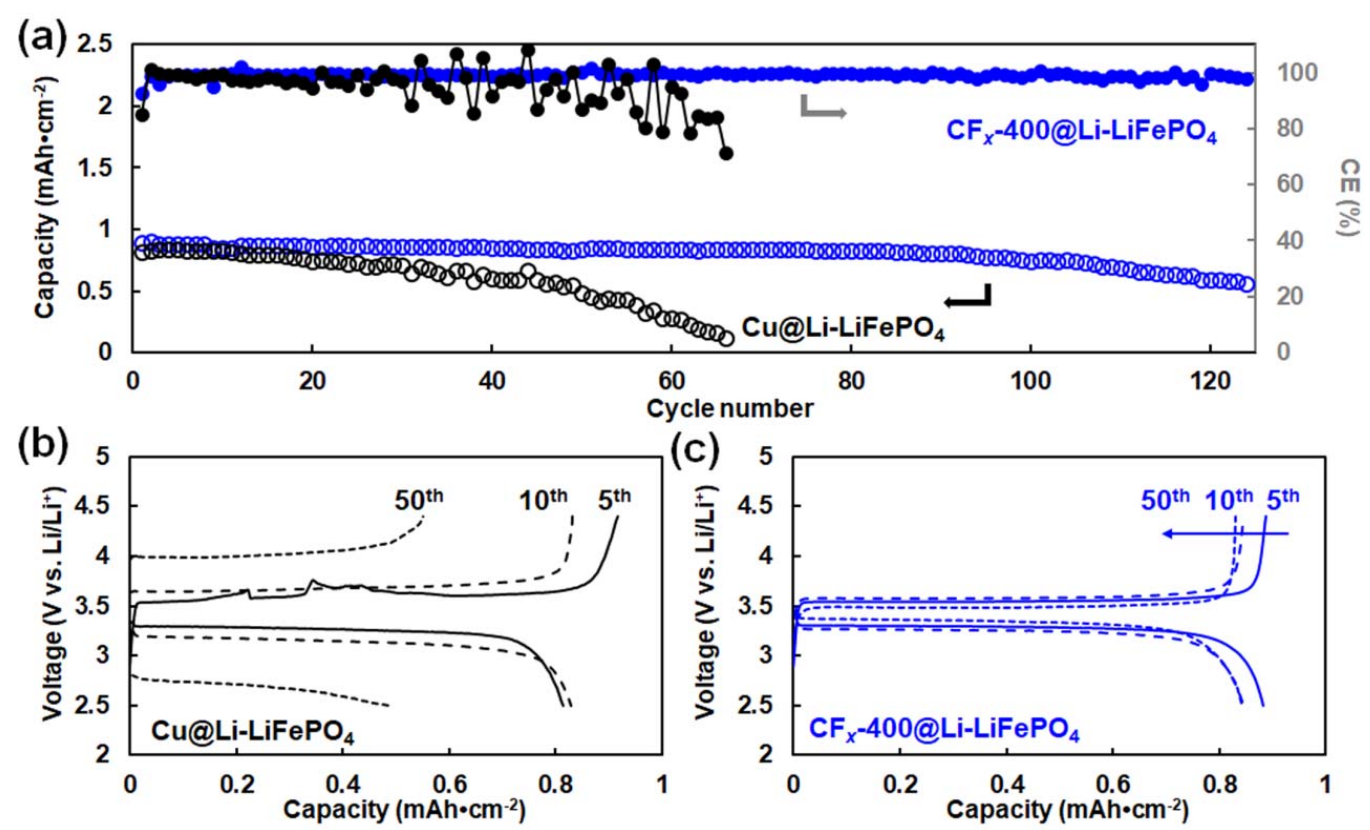

Fig. 7 (a) Capacity retentions and $\mathrm{CEs}$ of full cells using $\mathrm{LiFePO}_{4}$ as cathode and $\mathrm{Cu} @ \mathrm{Li}$ or $\mathrm{CF}_{x}-400 @ \mathrm{Li}$ as anode, and the charge-discharge curves of $\mathrm{Li}-\mathrm{LiFePO}_{4}$ cells using (b) $\mathrm{Cu} @ \mathrm{Li}$ or (c) $\mathrm{CF}_{x}-400 @ \mathrm{Li}$ anode.

Li-LiFePO4 cells, whereas the $\mathrm{Cu} @ \mathrm{Li}-\mathrm{LiFePO} 4$ cell exhibits a fast capacity fading below $0.5 \mathrm{mAh} \cdot \mathrm{cm}^{-2}$ at the 50 th cycle, with unstable and low CEs, and highly polarizing and fluctuating charge/discharge curves (Fig. 7b). Remarkably, the full cell using $\mathrm{CF}_{x}-400 @$ Li anode shows a stable cycling over 120 cycles (Fig. 7a), with almost unchanged polarizations upon cycling (Fig. 7c). The capacity retention of the $\mathrm{CF}_{x}-400 @ \mathrm{Li}^{-} \mathrm{LiFePO}_{4}$ full cell is $\sim 70 \%$ at the 120 th cycle, indicating a high utilization ratio of active $\mathrm{Li}$ in the practical condition of $\mathrm{N} / \mathrm{P}$ ratio $\sim 3$.

\section{Conclusions}

In this work, the cycling stability of Li metal anode was studied in a $\mathrm{CF}_{x}-400$ framework. Compared to the 2D structure consisted of large $\mathrm{CF}_{x}$ flakes, the investigated 3D framework with down-sized $\mathrm{CF}_{x}-400$ particles and $\mathrm{LiF}$-incorporated $\mathrm{Li}^{+}$ conducting channels could minimize the increase of interfacial impedance caused by the low electronic conductivity of fluorocarbon, and accommodate uniform and high-loading Li plating/stripping for long-term cycling. Based on the synergism of enriched fluorinated sites and fast $\mathrm{Li}^{+}$conducting channels in the $\mathrm{CF}_{x}-400$ framework, the Li metal cycling stability was significantly improved at various current densities (up to 3 $\mathrm{mA} \cdot \mathrm{cm}^{-2}$ ) and capacities (up to $3 \mathrm{mAh} \cdot \mathrm{cm}^{-2}$ ), and improved Li$\mathrm{LiFePO}_{4}$ full cell performance with a practical N/P ratio of 3 was also demonstrated.

Supporting Information: available free of charge via the internet at http://www.whxb.pku.edu.cn.

\section{References}

(1) Armand, M.; Tarascon, J. M. Nature 2008, 451, 652.

\section{doi: $10.1038 / 451652 \mathrm{a}$}

(2) Goodenough, J. B. Energy Storage Mater. 2015, 1, 158. doi: 10.1016/j.ensm.2015.07.001

(3) Xu, W.; Wang, J.; Ding, F.; Chen, X.; Nasybulin, E.; Zhang, Y.; Zhang, J. G. Energy Environ. Sci. 2014, 7, 513. doi: 10.1039/C3EE40795K

(4) Jiao, S.; Zheng, J.; Li, Q.; Li, X.; Engelhard, M. H.; Cao, R.; Zhang, J. G.; Xu, W. Joule 2018, 2, 110. doi: 10.1016/j.joule.2017.10.007

(5) Liu, F. F.; Zhang, Z. W.; Ye, S. F.; Yao, Y.; Yu, Y. Acta Phys. -Chim. Sin. 2021, 37, 2006021. [刘凡凡, 张志文, 叶淑芬, 姚雨, 余彦. 物 理化学学报, 2021, 37, 2006021.] doi: 10.3866/PKU.WHXB202006021

(6) Cheng, X.; Zhang, R.; Zhao, C.; Zhang, Q. Chem. Rev. 2017, 117, 10403. doi: 10.1021 acs.chemrev.7b00115

(7) Zheng, J.; Engelhard, M. H.; Mei, D.; Jiao, S.; Polzin, B. J.; Zhang, J. G.; Xu, W. Nat. Energy 2017, 2, 17012. doi: 10.1038/nenergy.2017.12

(8) Shi, Q.; Zhong, Y.; Wu, M.; Wang, H.; Wang, H. Proc. Natl. Acad. Sci. U.S.A. 2018, 115, 5676. doi: 10.1073/pnas. 1803634115

(9) Ding, F.; Xu, W.; Graff, G. L.; Zhang, J.; Sushko, M. L.; Chen, X.; Shao, Y.; Engelhard, M. H.; Nie, Z.; Xiao, J.; et al. J. Am. Chem. Soc. 2013, 135, 4450. doi: 10.1021/ja312241y

(10) Yu, H.; Zhao, J.; Ben, L.; Zhan, Y.; Wu, Y.; Huang, X. ACS Energy Lett. 2017, 2, 1296. doi: 10.1021/acsenergylett.7b00273

(11) Ren, X.; Zhang, Y.; Engelhard, M. H.; Li, Q.; Zhang, J. G.; Xu, W. ACS Energy Lett. 2018, 3, 14. doi: 10.1021/acsenergylett.7b00982

(12) Chen, S.; Zheng, J.; Mei, D.; Han, K. S.; Engelhard, M. H.; Zhao, W.; Xu, W.; Liu, J.; Zhang, J. G. Adv. Mater. 2018, 30, 1706102. 
doi: 10.1002/adma.201870144

(13) Ran, Q.; Sun, T. Y.; Han, C. Y.; Zhang, H. N.; Yan, J.; Wang, J. L. Acta Phys. -Chim. Sin. 2020, 36, 1912068. [再琴, 孙天霷, 韩冲宇, 张浩楠, 颜剑, 汪靖伦. 物理化学学报, 2020, 36, 1912068.] doi: 10.3866/PKU.WHXB201912068

(14) Liang, X.; Pang, Q.; Kochetkov, I. R.; Safont Sempere, M.; Huang, H.; Sun, X.; Nazar, L. F. Nat. Energy 2017, 2, 17119. doi: 10.1038/nenergy.2017.119

(15) Cha, E.; Patel, M. D.; Park, J.; Hwang, J.; Prasad, V.; Cho, K.; Choi, W. Nat. Nanotechnol. 2018, 13, 337. doi: 10.1038/s41565-018-0061-y

(16) Tu, Z.; Choudhury, S.; Zachman, M. J.; Wei, S.; Zhang, K.; Kourkoutis, L. F.; Archer, L. A. Nat. Energy 2018, 3, 310. doi: 10.1038/s41560-018-0096-1

(17) Meng, J.; Chu, F.; Hu, J.; Li, C. Adv. Funct. Mater. 2019, 29, 1902220. doi: 10.1002/adfm.201902220

(18) Guo, F.; Chen, P.; Kang, T.; Wang, Y. L.; Liu, C. H.; Shen, Y. B.; Lu, W.; Chen, L. W. Acta Phys. -Chim. Sin. 2019, 35, 1365. [郭峰, 陈鹏, 康拓, 王亚龙, 刘承浩, 沈炎宾, 卢威, 陈立桅. 物理化学学报, 2019, 35, 1365.] doi: 10.3866/PKU.WHXB201903008

(19) Liu, Y.; Zheng, L.; Gu, W.; Shen, Y. B.; Chen, L. W. Acta Phys. Chim. Sin. 2021, 37, 2004058. [刘亚, 郑否, 谷巍, 沈炎宾, 陈立桅. 物理化学学报, 2021, 37, 2004058.] doi: 10.3866/PKU.WHXB202004058

(20) Zhu, G. L.; Zhao, C. Z.; Yuan, H.; Nan, H. X.; Zhao, B. C.; Hou, L.
P.; He, C. X.; Liu, Q. B.; Huang, J. Q. Acta Phys. -Chim. Sin. 2021, 37, 2005003. [朱高龙, 赵辰孜, 袁洪, 南皓雄, 赵铂琛, 侯立鹏, 何传新, 刘全兵, 黄佳琦. 物理化学学报, 2021, 37, 2005003.] doi: 10.3866/PKU.WHXB202005003

(21) Zhang, X. Q.; Cheng, X. B.; Chen, X.; Yan, C.; Zhang, Q. Adv. Funct. Mater. 2017, 27, 1605989. doi: 10.1002/adfm.201605989

(22) Markevich, E.; Salitra, G.; Chesneau, F.; Schmidt, M.; Aurbach, D. ACS Energy Lett. 2017, 2, 1321. doi: 10.1021/acsenergylett.7b00300

(23) Fan, X.; Chen, L.; Borodin, O.; Ji, X.; Chen, J.; Hou, S.; Deng, T.; Zheng, J.; Yang, C.; Liou, S.; et al. Nat. Nanotechnol. 2018, 13, 1191. doi: 10.1038/s41565-018-0183-2

(24) Fan, X.; Ji, X.; Chen, L.; Chen, J.; Deng, T.; Han, F.; Yue, J.; Piao, N.; Wang, R.; Zhou, X.; et al. Nat. Energy 2019, 4, 882. doi: $10.1038 / \mathrm{s} 41560-019-0474-3$

(25) Lin, D.; Liu, Y.; Chen, W.; Zhou, G.; Liu, K.; Dunn, B.; Cui, Y. Nano Lett. 2017, 17, 3731. doi: 10.1021/acs.nanolett.7b01020

(26) Peng, Z.; Zhao, N.; Zhang, Z.; Wan, H.; Lin, H.; Liu, M.; Shen, C.; He, H.; Guo, X.; Zhang, J. G.; Wang, D. Nano Energy 2017, 39, 662. doi: 10.1016/j.nanoen.2017.07.052

(27) Wang, M.; Peng, Z.; Luo, W.; Ren, F.; Li, Z.; Zhang, Q.; He, H.; Ouyang, C.; Wang, D. Adv. Energy Mater. 2019, 9, 1802912. doi: 10.1002/aenm.201802912

(28) Fan, X.; Ji, X.; Han, F.; Yue, J.; Chen, J.; Chen, L.; Deng, T.; Jiang, J.; Wang, C. Sci. Adv. 2018, 4, eaau9245. doi: 10.1126/sciadv.aau9245 